\title{
Genotoxicity Studies of Arsenic, Lead and Their Interaction in Wistar Rats
}

\author{
J. K. Raval", Vikas Jaiswal, J. M. Patel, P. D. Vihol, H. C. Parmar, \\ J. H. Patel and B. P. Joshi \\ Department of Veterinary Pathology, Vanbandhu College of Veterinary Science and A.H, \\ Navsari Agricultural University - Navsari-396450, Gujarat, India \\ *Corresponding author
}

A B S T R A C T

\section{Keywords \\ Genotoxicity, Lead \\ acetate, Sodium arsenite, Wistar rats \\ Article Info \\ Accepted: \\ 25 October 2018 \\ Available Online: \\ 10 November 2018}

The present study was carried out on sixty Wistar rats divided into groups I, II, III, IV and $\mathrm{V}$ for a period of 28 days to study genotoxic effects induced by arsenic, lead and their mixture. The group I served as control while group II, III and IV were gavaged with sodium arsenite, lead acetate and mixture of both metals, respectively. The group V served as positive control which was treated with cyclophosphamide. Chromosomal aberration assay and micronuclei assay was studied from bone marrow cells of femur bone of all the rats. Arsenic and lead alone was equally genotoxic to that of mixture of both metals while their genotoxic potential was less than cyclophosphamide.

\section{Introduction}

Exposure of humans and animals to heavy metals through long-term ingestion of contaminated drinking water and its attendant health problems has been widely reported (Oyeronke et al., 2007). Arsenic is second only to lead as a source of heavy metal intoxication to domestic animal species (Sahli, 1982; Osweiler et al., 1985). It is also known that arsenic interact with other metals thereby potentiating its effects or vice versa. Very little research information is available on toxicity of mixture of arsenic and lead. We therefore describe in this study the genotoxicological effects of dietary coadministration of sodium arsenite and lead acetate in Wistar rats.

\section{Materials and Methods}

The experiment was conducted on Wistar rats after taking approval from IAEC (Institutional Animal Ethics Commiteee) and CPCSEA (Committee For Purpose of Control and Supervision of Experimentation on Animals).The subacute toxicity study on the interaction of sodium arsenite and lead acetate was evaluated on 60 Wistar rats divided into 5 different groups each consisting of 6 male and 6 female rats. The group I served as a control and was given only deionised water orally. The group II and III were orally dosed with sodium arsenite $(4 \mathrm{mg} / \mathrm{kg}$ body weight $)$ and lead acetate (53 mg/kg body weight) respectively for 28 days. The group IV was gavaged with mixture of sodium arsenite (4 
$\mathrm{mg} / \mathrm{kg}$ body weight) and lead acetate (53 $\mathrm{mg} / \mathrm{kg}$ body weight) for 28 days. The group $\mathrm{V}$ was kept as a positive control for genotoxicity study, which was given cyclophosphamide (20 $\mathrm{mg} / \mathrm{kg}$ body weight) intraperitoneally 24 hour before the terminal sacrifice. At the end of the experiment all the rats were subjected to terminal sacrifice and bone marrow cells from femur were collected. Chromosomal aberration assay was studied according to the method given by (Malhi and Grover, 1987) and (Chauhan et al., 2000) Micronuclei assay was studied as per the method given by (Zhong and Siegel, 2000). The data generated during experiment were subjected to statistical analysis by using standard statistical procedures given by (Snedecor and Cochran, 1980).

\section{Results and Discussion}

Chromosomal aberrations were scored as type -I (excluding gaps) and type-II (excluding gaps and pulverization) and presented in Table I.

The mean numbers of chromosomal aberrations both type I \& II from group II, III and IV revealed significant increase as compared to group I (negative control) on 28th day post treatment. Among different treatment groups (i.e. II, III and IV) there was insignificant difference in chromosomal aberrations both type I \& II. The known genotoxic compound cyclophosphamide showed significantly higher percentage than all the treatment groups. The structural chromosomal aberrations noticed among different groups were gaps, breaks, fragments, exchange and ring chromosomes. Chromosomal aberrations arise from damage to structural integrity of chromosomes.

The mean number of micronuclei/2000 Polychromatic erythrocytes (PCE) found in groups I, II, III, IV and V were 1.19, 3.30, $3.35,3.79$ and 13.39 , respectively as presented in Table I. The mean number of micronuclei found in group $\mathrm{V}$ was significantly higher than group I, II, III and IV as it was treated with cyclophosphamide. Among different treatment groups there was no significant difference in micronuclei on 28th day post treatment.

PCE/TE (Total erythrocytes) ratio was lowest in positive control (group V) and highest in negative control rats (group I). All the three treatment groups (II, III, and IV) showed significantly decreased value of PCE/TE ratio as compared to negative control.

Table.1 Effect of arsenic, lead and mixture of arsenic and lead on different genotoxicity parameters (Mean \pm S.E.) of rats on $28^{\text {th }}$ day post treatment

\begin{tabular}{|l|l|l|l|l|l|}
\hline Parameter & $\begin{array}{l}\text { Group } \\
\text { Control) }\end{array}$ & $\begin{array}{l}\text { Group II } \\
\text { (Sodium } \\
\text { Arsenite) }\end{array}$ & $\begin{array}{l}\text { Group III } \\
\text { (Lead } \\
\text { Acetate) }\end{array}$ & $\begin{array}{l}\text { Group IV } \\
\text { (Sodium } \\
\text { Arsenite } \\
\text { Lead Aceate) }\end{array}$ & $\begin{array}{l}\text { Group V } \\
\text { Control } \\
\text { Cyclophosphamaide) }\end{array}$ \\
\hline Micronuclei /2000 PCE & $1.19^{\mathrm{a}} \pm 0.37$ & $3.30^{\mathrm{b}} \pm 0.37$ & $3.35^{\mathrm{b}} \pm 0.37$ & $3.79^{\mathrm{b}} \pm 0.37$ & $13.39^{\mathrm{c}} \pm 0.74$ \\
\hline PCE/TE & $114.39^{\mathrm{c}} \pm 2.22$ & $106.59^{\mathrm{b}} \pm 1.88$ & $102.19^{\mathrm{b}} \pm 1.65$ & $101.00^{\mathrm{b}} \pm 1.73$ & $74.60^{\mathrm{a}} \pm 1.92$ \\
\hline $\begin{array}{l}\text { Chromosomal } \\
\text { Aberration assay I (\%) }\end{array}$ & $1.19^{\mathrm{a}} \pm 0.49$ & $2.25^{\mathrm{b}} \pm 0.49$ & $2.24^{\mathrm{b}} \pm 0.33$ & $2.71^{\mathrm{b}} \pm 0.49$ & $8.00^{\mathrm{c}} \pm 0.89$ \\
\hline $\begin{array}{l}\text { Chromosomal } \\
\text { Aberration assay II (\%) }\end{array}$ & $0.85^{\mathrm{a}} \pm 0.22$ & $2.27^{\mathrm{b}} \pm 0.18$ & $2.26^{\mathrm{b}} \pm 0.23$ & $2.44^{\mathrm{b}} \pm 0.34$ & $5.54^{\mathrm{c}} \pm 0.37$ \\
\hline
\end{tabular}

Superscript should be read row wise for mean comparison.

Mean with similar superscripts in row do not differ significantly $(\mathrm{P}<0.05)$ 
In the present study various structural chromosome aberrations (gaps, breaks, fragments, exchange and ring chromosomes) were observed. Out of these, gaps were excluded from statistical analysis as it could arise from the despiralisation in the metaphase chromosome and were observed in control animals also. Pulverization indicated genotoxic as well as cytotoxic effect and hence was excluded during statistical analysis as suggested by (Adler, 1984). As accordance with the present findings (Lee et al., 2004) was also reported increased frequency of chromosomal aberration with arsenic treatment, they further suggested that genotoxicity might be mediated by the induction of oxidative stress. Similarly, (Jadhav, 2005) also found increase in micronuclei formation and chromosomal aberrations with mixture of eight metals inclusive of arsenic and lead.

Micronuclei are thought to arise from chromatid or chromosome fragments detached from a chromosome after breakage (Moore et al., 1997). This micronucleus does not integrate into the daughter nuclei and remains as a separate entity. Consistent to present study (Oyeronke et al., 2007) also reported presence of micronucleated polychromatic erythrocytes in the bone marrow cells of the rats treated with mixture of sodium arsenite and lead acetate.

The overall findings of both the micronuclei and chromosomal aberration study suggested that arsenic and lead when administered alone were equally genotoxic to that of mixture of both the metals at the given dose level while their genotoxic potential was less than the positive control.

\section{Acknowledgment}

Authors are highly thankful to Department of Veterinary Pathology, College of Veterinary sciences and A.H., Anand Agricultural University, Anand- 388001 for providing necessary technical guidance and laboratory facilities.

\section{References}

Adler R. 1984. Conversion: mimicry of somatic symptoms. Schweiz Med Wochenschr, 114(49):1814-8.

Chauhan L K S, Pant N, Gupta S K and Srivastava S P. 2000. Induction of chromosome aberrations, micronucleus formation and sperm abnormalities in mouse following carbofuran exposure. Mutat. Res., 465: 123-129.

Jadhav S H. 2005. Toxicodynamics of a mixture of selected groundwater metal contaminants in rats. Ph.D. Thesis submitted to Deemed University, Indian Veterinary Research Institute, Izzatnagar.

Lee D H, Blomhoff R and Jacobs D R. 2004. Is serum gamma glutamyltransferase a marker of oxidative stress? Free Radic. Res., 38: 535 - 539.

Malhi P K and Grover I S. 1987. Genotoxic effects of some organophosphorus pesticides: II. in vivo chromosomal aberration bioassay in bone marrow cells in rat. Mutat Res., 188: 45-51

Moore L E, Smith A H and Hopenhayn-Rich C. 1997. Micronuclei in exfoliated bladder cells among individuals chronically exposed to arsenic in drinking water. Cancer Epidemiol. Biomarkers Prev., 6(1):31-36.

Osweiler G D, Carson T L, Buck W B and Van Gelder G A. 1985. Clinical and Diagnostic Veterinary Toxicology, $3^{\text {rd }}$ eds., pp. 72-79.

Oyeronke A, Odunola Kazeem A, Akinwumi, Babatunde, Ogunbiyi and Oladimeji T. 2007. Interaction and enhancement of the toxic effects of sodium arsenite and 
lead acetate in Wistar rats. Afr. $J$. Biomed. Res 10: 59 - 65.

Sahli B P 1982. Arsenic concentrations in cattle liver, kidney, and milk. Vet Hum Toxicol., 24:173-174.

Snedecor G W and Cochran W G. 1980. Statistical methods. 7th edition, Iowa State University Press, Ames, Iowa.
Zhong B Z and Siegel P D. 2000. Induction of micronuclei following exposure to methylene di-phenyl diisocyanate: potential genotoxic metabolites. Toxicol. Sci., 58: 102-108.

\section{How to cite this article:}

Raval J. K., Vikas Jaiswal, J. M. Patel, P. D. Vihol, H. C. Parmar, J. H. Patel and Joshi B. P. 2018. Genotoxicity Studies of Arsenic, Lead and Their Interaction in Wistar Rats. Int.J.Curr.Microbiol.App.Sci. 7(11): 3536-3539. doi: https://doi.org/10.20546/ijcmas.2018.711.405 